可視化情報 Vol.12 Suppl. No.1（1992年 7 月）

\title{
22 線形せん断流ダクト内の球状粒子の運動
}

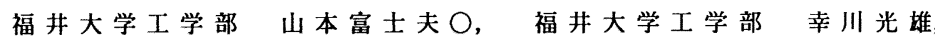 \\ 渋谷工業紋谷英樹, \\ 信越化学工業宮本浩幸, \\ 福井大学学生滒本竜哉, \\ Motion of Particles in Linear Shear Flows through a Duct \\ Fuji O YAMAMOTO*1, Mitsuo KOUKAWA*1 \\ Hideki MONYA*2, Hiroyuki MIYAMOTO*3, Tatsuya KAWAMOTO*4 \\ Linear shear flows with constant velocity gradients are made through \\ a duct by putting unequal-spacing parallel rods in it. The flow character- \\ istics of the shear flows are measured and motion of shepherical particles \\ is investigated in the duct. \\ Effects of the velocity gradients of linear shear flows at a high \\ Reynolds number on lift applied on a spherical particle are investigated \\ by photographing trajectories of a sphere falling in upward shear flows and \\ those of particles suspending in horizontal shear flows using a high speed \\ video system. It is made clear that lift is applied on a sphere from the \\ higher volocity side to the lower velocity side. \\ Key Words; Linear Shear Flow, Gas-Solid Two-phase Flows, Particle Motion, \\ Lif t Force,
}

\section{1. 緒言}

最近の固気二相流の数值シミュレーションの研究では, 粉粒体に働く揚力や抗力, 壁面 との反発と摩擦について単相流の中で行わ的た実験で得られた実験值を導入し, 計算の一 般化をはかりまたた など, 乱流特性の数值計算も行っている.このように固気二相流の数值シミュレーション はますます重要視されている.

実際の固気二相流では，管内気流は乱流せん断流をしているので，一様な単相流の中で

*1 Fukui University, Dept. of Mech. Engg., Bunkyo Fukui, 910, Japan.

*2 Sibuya Kogyo Co. Mameda-honmachi, Kanazawa-shi, 920 , Japan.

*3 Shinetsu Kagaku Kougyo Co. 2-1-5 Kitago, Takefu-shi, 915, Japan.

*4 Graduate School of Fukui University. 
得られた実験係数の值をそのままシミュレーションに用いるのは問題である. せん断乱流 中に置かれた円柱や球に働く揚力や坑力に関する研究は, 首流の場合には多く見られるが, 乱流の場合には少ない, くくに，揚力の作用方向が低レイノルズ数の層流の場合と乱流の 場合とでは反対になることはあまり知られていないようであるいいまた，せん断流による 揚力は無視されることが多いが, 鈶直管内では揚力は粒子の横方向の運動を支配するので, それを無視するのは妥当ではない。そこで著者らは平均速度こう配が一定で数％の乱れ度 を有する、いわゆる, 線形乱流せん断流の二次元ダクトを作った。 その流れの速度分布, 乱れ度分布, レイノルズ応力分布などのダクト特性と, 線形せん断流ダクト内の球状粒子 の運動をステレオ写真および高速度ビデオで記録し，解析した結果について報告する。

\section{2. 実験装置おょび実験方法}

2. 1 ダクトと不等間隔格子

図 1 (a)，(b)に実験装置の概略図と 座票を示す。座標の原点を不等間隔格 子の中心にとり, 気流の方向を $\mathrm{x}$ 方向 とする. 気流は, $\mathrm{y}$ 方向に直線的な速 度こう配を持ち $\mathrm{z}$ 方向には一様な二次 元せん断流を有する.ダクトは, $150 \mathrm{~mm}$ $\times 150 \mathrm{~mm}$ の鈶直吸込み形で, 写真撮影の 都合上，厚さ5 m m の透明アクリル板で作 られている。その全長は $2700 \mathrm{~mm}$ である. ダクトの入ロにベルマゥスを付け一っ

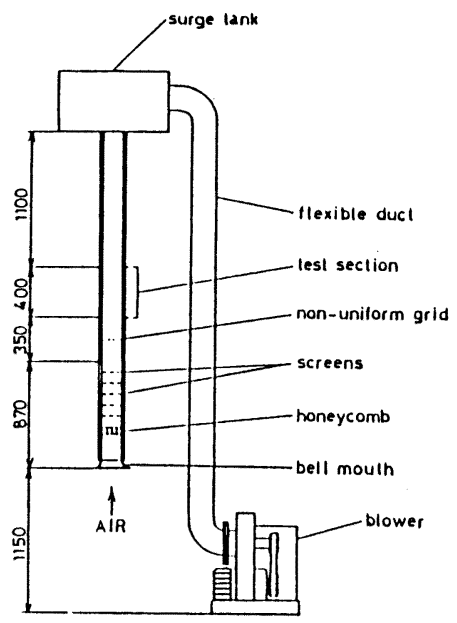

(a) Experiment a 1

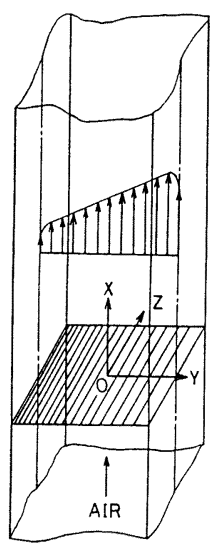

(b) Coordinate s y s t e m のハニカムと 5 枚のスクリーンを $100 \mathrm{~mm}$ Fig. 1 0utline of experimental apparatuces 間隔に置いて, 一様な気流が得られるように した.テストセクションでは, せん断格子の ない場合,一様な気流の最大平均流速は $20 \mathrm{~m} / \mathrm{s}$, 乱れ度は $1.4 \%$ でる。 また流速の調節にはブ ロワ出ロに付けられた弁を用いた。線形せん 断流を作るために, y 方向に不等間隔で配置 した直形 $3 \mathrm{~mm}$ の棒からなる格子をテストセ クションの上流 $250 \mathrm{~mm}$ のところに取り付けた 各丸棒間の間隔は 0 wen $-Z$ i enkiewicz(z) によ る非粘性流体の単純せん断流の作成理論を基 にしたが, そのままでは十分に一様な速度こ う配が得られないため, 試行錯誤的に格子の 間隔と調整と速度分布の測定とを繰り返し，

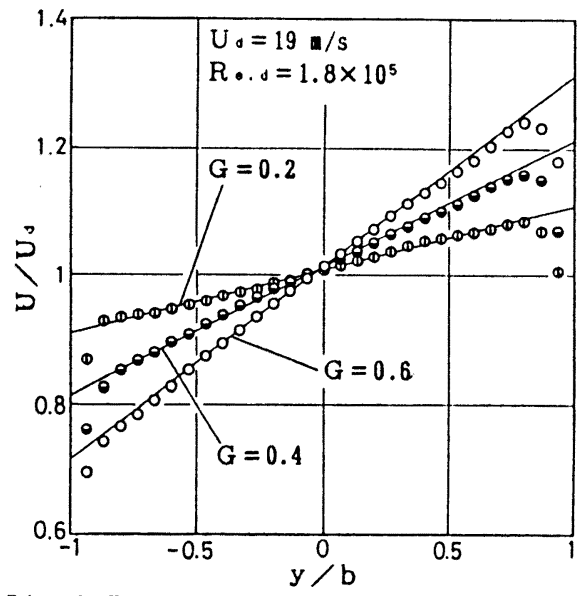

Fig. 2 Velocity distribution in the main flow direction 
無次元速度こう配 $\mathrm{G}\left(=\frac{\partial u}{\partial y} \frac{2 y}{U_{a}}\right)$ が $\mathrm{G}=0.2,0.4,0.6$ の一定の 3 種類の線形せん断流を得た。図2 に速度分布（Uは気流の時間平均速度, U d は気流のダクト断面平均速度) を示す。いず れの速度こう配についても良好な直線性が得られている。なお,テストセクションの区間 では，主流方向に㧍ける速度こう配は一定に保たれた。また，断面平均流速をUd=12〜19m /sの間で变化させても速度こう配に变化はなかった。また，粒子の軌跡をを高速度ビデオ を用いて撮影するに当たり,このダクトを水平に配置したが,この場合のダクト特性す前 に述べた鉿直配管の場合と同様の特性を示した。流速Uの测定には標準ピト一管を用いた。 また, $\mathrm{x}$ 方向と $\mathrm{y}$ 方向の速度分布の乱れ度やレイノルズ応力の測定には, 熱線流速計の $\mathrm{I}$ 形プローブを回転させる方法を用いた。これらのデー夕処理のために, 熱線流速計, A Dコンバータ、およびパーソナルコンピュータからなる自動計測システムを用いた。実験 ダクトの乱れ度 $T u$ を図 3 にレイノルズ応力の分布を図 4 に示す.

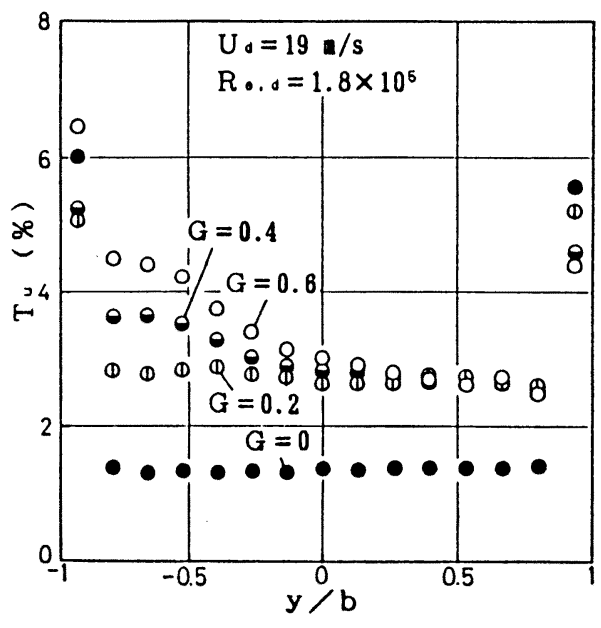

Fig. 3 Turbulence intensity of the $x$ component

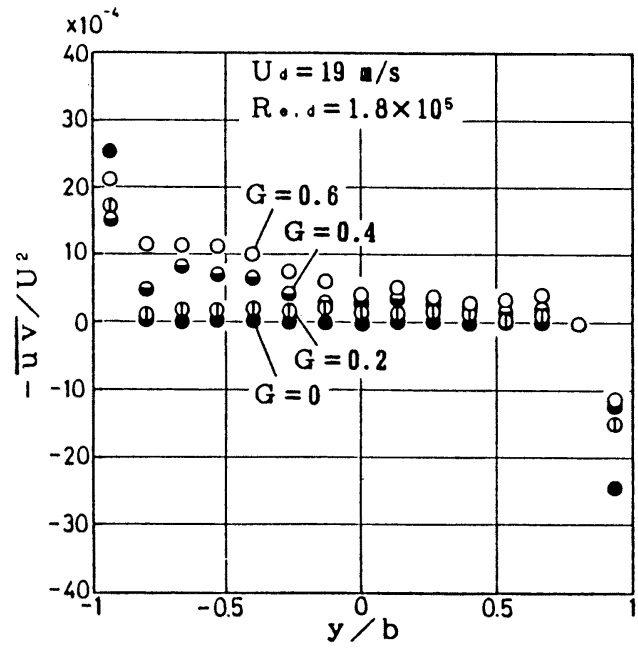

Fig. 4 Reynolds stress distribution

\section{2 線形せん断流中の落下球の軌跡}

線形せん断流中の球の運動軌跡に及ぼす揚力の影響を調べるために, 落下球の軌跡をス トロボで照明して付きのカメラで撮影する. 供試球は直形が $\mathrm{d}=5 \mathrm{~mm}$ で密度 $\mathrm{g}$ が $\rho=4470 \mathrm{~kg} / \mathrm{m}^{3}$ のガラス球である.

2. 3 粒子の運動の撮影 ダクト内を運動する粒子を追跡する方法として, 本実験で は, 大量の粒子が高速で移動するので, 高速度ビデオを用いた。使用したビデオは, 1 秒 間に 400 画面取り込み N T S C 方式 (60画面/秒) で再生される. カメラをダクトの鈶直 上方に配置し, $x / 2 b=6.67(x=1000 \mathrm{~mm}, 2 \mathrm{~b}$ はダクトの幅) の所を撮影した. たた, 使用した 粒子は直径 $\mathrm{d}=2.8215 \mathrm{~mm}$, 密度 $\rho=1125 \mathrm{~kg} / \mathrm{m}^{3}$ のむのを使用した.また, 撮影された映像から $\mathrm{X}$

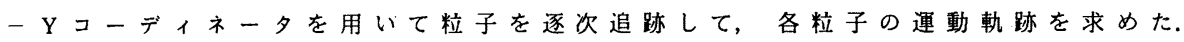




\section{3. 害験結果とその考察}

3. 1 鉛直ダクト内の落下球の軌跡

図 $5(a) \sim(c)$ は, 実験ダクト内の上向 き線形せん断流の中を落下する球の運動 軌跡のストロボ写真である。これらの写 真より, 軌跡は落下するにつれて鉛直線 ょり気流の低速側に偏向している。これ ょり, 落下球は気流の高速側加ら低速側 に揚力を受けていることがわかる。また。 軌跡の鉛直線からのずれが速度こう配 $\mathrm{G}$ ととあに大きくなることが認められる。

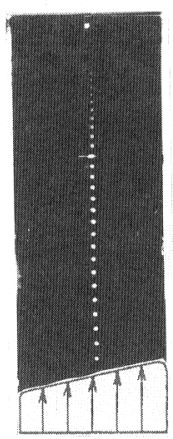

(a) $G=0.2$

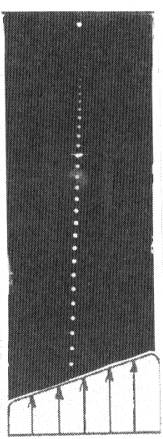

(b) $\quad G=0.4$

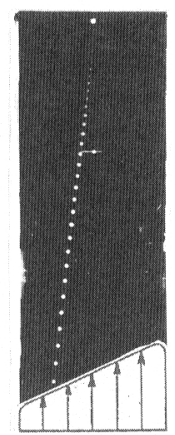

(c) $G=0.6$

Fig. 5 Photograph of a sphere falling in a shear flow

3. 2 粒子に働く揚力と偏向角度 $\theta$ 図 6 は $x / 2 b=6.67$ で数百個の粒子を追跡し, 得ら机 た結果をまとめ偏向角度の頻度を七ストグラムで表したものである。速度の高速側から低 速側に移動した粒子を一で表し、これと逆方向に移動したあのを十とした。これからす多 数の粒子がダクト内の気流速度の高速側から低速側に偏向していることがわかる。また, 図7 はx/2b=6.67の断面において, それぞれの場所について粒子の偏向角度を求めた図であ る.この図より気流の速度の高い側から低い側に移動する粒子の多いことがわかる。

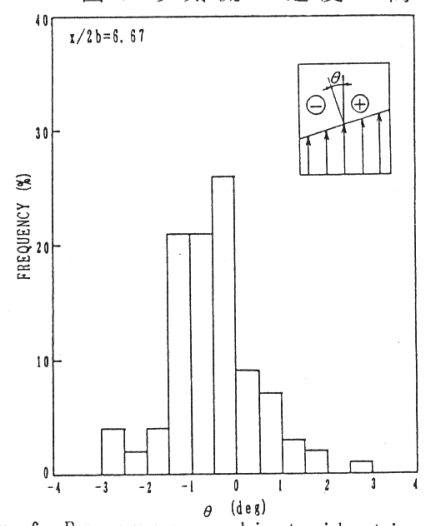

Fig. 6 Frequency distribution of angle $\theta$

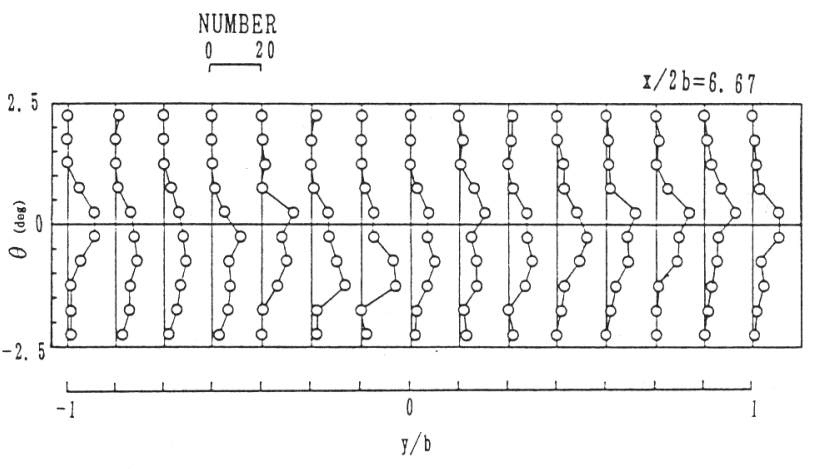

Fig. 7 Particle number distribution for each angle $\theta$ in the y direction

\section{4. 結 言}

1) 本実験で使用した不等間隔格子を備えたダクトにより,テストセクションにおいて, 無次元速度こう配 $G=0.2$, 0.4 . 0 . 6 である速度こう配が一定のせん断流れを得た。

2 ) 気流と粒子の相対速度で定義された粒子のレイノルズ数が 600 以上の場合，粒子は近 寄り流れの高速側から低速側へ向かう揚力を受けその方向に偏向して運動する.

参考文献

(1) 山本, 平成元年度科学研究費補助金 (一般研究C) 研究成果報告書, 63550131 (1990).

(2) Owen, P.R. and Zienkiewicz,H.K., J.Fluid Mech.,2-6(1957), 521-531. 